\title{
Seizing The InItiative on SeXual AsSaUlt in THE UNITED STATES MILITARY: THE WAY FORWARD
}

\author{
ANDREW KUHLENHOELTER ${ }^{*}$
}

\section{INTRODUCTION}

In February 2018, several hundred United States Army recruits packed onto buses bound for Fort Leonard Wood for Basic Combat Training ("BCT"). ${ }^{1}$ Nervous energy filled the air as the recruits discussed what awaited upon their arrival. No one hesitated to postulate his or her own theory backed up by accounts of friends or YouTube videos. Regardless of the specific details, everyone was sure that there would be extensive yelling, running, and pushups. Close to midnight, after two hours of travel, the buses finally stopped with two brownhatted drill sergeants immediately outside the doors. Silence gripped the air as the recruits nervously awaited the impending boarding and the beginning of the dreaded "shark attack" but neither came. Instead, the recruits were sternly ordered off the bus and into a reception area where, within an hour, they were briefed on sexual assault and harassment.

The shark attack eventually came and went, but the briefings and training on sexual assault and harassment continued. Lieutenant colonels, ${ }^{3}$ followed by their menacing sergeant major counterparts, briefed their new recruits on sexual harassment and assault and explained that they would not be tolerated in the United States Army. In separate briefings, majors and captains down to the company commander echoed the words of their superiors. ${ }^{4}$ Finally, recruits were required to pass an exam asking: (1) whether certain behaviors constituted sexual assault and harassment; (2) the difference between a restricted and unrestricted report; and (3) the identity of the unit's Sexual Harassment Assault Reporting and Prevention ("SHARP") representative, among other relevant questions. Later in the ten-week BCT course, demonstrations and training were done to instruct the recruits on consent and other inappropriate and appropriate behaviors.

* J.D. Candidate, 2021, Indiana University Robert H. McKinney School of Law; B.A, 2016, Philosophy, Brigham Young University. Enlisted in the Indiana Army National Guard February 2018 with the current rank of second lieutenant. Opinions and conclusions in this article are solely those of the author. They do not reflect the views of the Indiana Army National Guard, the National Guard Bureau, the Department of the Army, or any other government agency.

1. Author's personal experience.

2. The shark attack, as it is commonly known, is a training technique designed to induce stress on new recruits. Typically, drill sergeants will inspect their new recruits until they find a deficiency. Once a deficiency is found, the drill sergeants immediately converge on the deficient recruit by aggressively asking him questions or by administering corrective physical training while the soldier works to correct the deficiency. Inevitably, nearly all new recruits are the subject of this type of unpleasant attention.

3. See infra Appendices A and B for rank and unit structure.

4. See infra Appendices A and B for rank and unit structure. 
Although purely anecdotal and reflective of only one branch of the military, this training seems to contrast starkly with the experience of freshman Senator Martha McSally as described in March of 2019 during a hearing for the Senate Committee on Armed Services. During her testimony, McSally, one of the first women to fly combat missions and command a combat unit, revealed that she was raped during her illustrious twenty-six year career in the United States Air Force. $^{5}$ Like so many, she did not report it at the time and spent many years blaming herself and feeling guilt and shame. ${ }^{6}$ Eventually, following the example of others who were brave enough to speak out, she did report but was stunned and horrified by how she was treated afterward. ${ }^{7}$

McSally went so far as to say, like many others, that the system was "raping her all over again." "She even considered leaving the Air Force after eighteen years. ${ }^{9}$ In the end, however, she courageously decided to stay and lead the fight against sexual assault from within. ${ }^{10}$ She retired eight years later with the rank of Colonel. ${ }^{11}$ Many of the changes reflected in the United States Military of 2018 are because of people like Martha McSally. Unfortunately, her story is all too familiar for military sexual assault survivors. ${ }^{12}$

Although the military has improved since Senator McSally's experience, significant problems remain. 2018 saw a year-on-year statistical increase in the number of sexual assaults against women in the military. ${ }^{13}$ Twenty-one percent of those who reported sexual assaults in 2018 also reported incidents of retaliation arising from their report. ${ }^{14}$ Additionally, twenty-four percent of women and six percent of men reported experiences of sexual harassment. ${ }^{15}$ Finally, one-third of

5. Hearing to Receive Testimony on the Military Services' Prevention of and Response to Sexual Assault before the US Sen. Sub. Comm. On Personnel and Comm. on Armed Services, 116th Cong. 1, 11, (2019) (statement of Martha McSally), https://www.armed-services.senate.gov/imo/ media/doc/19-21_03-06-19.pdf [https://perma.cc/UXU4-FRHX]; Helene Cooper et al., 'I Too, Was a Survivor': Senator McSally Ends Years of Silence, N.Y. TIMES (Mar. 26, 2019), https://www. nytimes.com/2019/03/26/us/senator-martha-mcsally-rape-assault.html[perma.cc/MC5A-ZUQ2].

6. Hearing to Receive Testimony on the Military Services' Prevention of and Response to Sexual Assault, supra note 5, at 11.

7. Id.

8. Id.

9. Id. Twenty years of service is required to access full military retirement benefits. See Computing Retired Military Pay, MiLITARY.COM (Feb. 22, 2021), https://www.military.com/ benefits/military-pay/computing-retired-military-pay.html [https://perma.cc/3K3X-DTX4].

10. Hearing to Receive Testimony on the Military Services' Prevention of and Response to Sexual Assault, supra note 5, at 11.

11. Id. at 10; see Appendices A and B.

12. Cooper et al., supra note 5 .

13. 2018 U.S. Dep't of Def. Rep. on Sexual Assault in the Military 3, https://www. sapr.mil/sites/default/files/DoD_Annual_Report_on_Sexual_Assault_in_the_Military.pdf [perma.cc/896Q-R8CP].

14. Id. at 12 .

15. Id. See Appendix C. 

THE UNITED STATES MILITARY

women across the military failed to affirmatively respond when asked if the military justice system would treat them with dignity and respect. ${ }^{16}$ The purpose of this Note is to build on the progress of the last two decades by evaluating possible reforms with the goal of reducing and eliminating sexual assault and harassment within the ranks.

Many critics claim that the military's continued reliance on commanders' prosecutorial discretion in sexual assault cases is misguided and ripe for reform. ${ }^{17}$ In the military justice system, commanders have sole discretion on whether to refer charges for prosecution in cases involving service members under their command. Opponents of the model claim that it is, at best, a procedurally unsound and unnecessary hurdle for just outcomes for victims and the accused ${ }^{18}$ and, at worst, a process that allows commanders to ignore victims and fuel the toxic culture of the military without accountability. ${ }^{19}$ Defenders of the system claim that it is a necessary mechanism to maintain good order and discipline and that commanders should be the focal point of efforts to combat sexual assault. ${ }^{20}$

This Note takes the position that although stripping commanders of prosecutorial discretion could lead to a more transparent and procedurally sound system, removing this power would not lead to lasting change and ignores the military's underlying cultural problems. Because empirical data and independent review of commander prosecutorial decisions suggest that commanders are not

16. Office of People Analytics, Workplace and Gender Relations Survey of Active Duty Members xii (2019), https://www.sapr.mil/sites/default/files/Annex_1_2018_ WGRA_Overview_Report.pdf [perma.cc/97WS-DP9H].

17. See, e.g., Alexandra Lohman, Silence of the Lambs: Giving Voice to the Problem of Rape and Sexual Assault in the United States Armed Forces, 10 Nw. J. L. \& Soc. Policy 230, 261 (2015); Colleen Dalton, The Sexual Assault Crisis in the United States Air Force Academy, 11 CARdozo Women's L.J. 177, 193 (2004); Michal Buchhandler-Raphael, Breaking the Chain of Command Culture: A Call for an Independent and Impartial Investigative Body to Curb Sexual Assaults in the Military, 29 WIS. J.L. GENDER \& SOC'Y 341, 355 (2014); Major Elizabeth Murphy, The Military Justice Divide: Why Only Crimes and Lawyers Belong in the Court-Martial Process, 220 MiL. L. Rev. 129, 130 (2014); Military Justice Improvement Act, GiLliBrand, https://www. gillibrand.senate.gov/mjia [perma.cc/5BB9-64AA]; Military Justice Improvement Act of 2013, S. 1752, 113th Cong. (2013).

18. Murphy, supra note 17 , at 130.

19. Lohman, supra note 17, at 261.

20. DeP'T OF Def., Sexual Assualt Accountability and Investigation Task Force 13 (Mar. 2019), https://media.defense.gov/2019/May/02/2002127159/-1/-1/1/SAAITF_REPORT.PDF [perma.cc/5WUM-3S42]; Shelbi Nicole Keehn, Striking A Balance Between Victim and Commanding Officer: Why Current Military Sexual Assault Reform Goes Too Far, 48 CoLUM. J.L. \& Soc. Probs. 461, 490 (2015); Tom Vanden Brook, Sen. Martha McSally Pushes to Criminalize Sexual Harassment in Military, add Lawyers for Victims, USA TODAY (May 11, 2019), https://www.usatoday.com/story/news/politics/2019/05/11/mcsally-criminalize-sexual-harassmentadd-lawyers-victims/1153267001/ [perma.cc/45BK-QT5R]. 
abusing their discretion, ${ }^{21}$ future reforms should work to change the United States military's culture by shifting sexist attitudes and beliefs about women and sexual assault, which lead to unjust outcomes for victims. ${ }^{22}$ Making sexual harassment an enumerated Uniform Code of Military Justice ("U.C.M.J.") violation, broadening the definition of retaliation, and implementing reforms to "degender" the military will facilitate and drive necessary cultural change. ${ }^{23}$ These reforms will correct harmful gender stereotypes and the negative perception of female otherness in a military environment by rectifying cognitive biases. As such, they are more likely to yield progress on the issues of sexual assault and harassment.

To prove this thesis, this Note will first review sexual assault in the United States military, focusing on recent statistics and major reforms. Then, this Note will review the arguments for and against commanders' discretion and analyze the recent data released on the subject. Next, this Note will review the sexual assault policies and statistics of the United Kingdom with an emphasis on their recent decision to strip commanders of prosecutorial discretion. Finally, I will analyze Norway's military, which has worked for years to degender its military culture and propose reforms that will drive cultural change.

\section{BACKGROUND}

The U.C.M.J. is the code of military criminal law and procedure that governs U.S. service members worldwide. ${ }^{24}$ In line with the idea that the military operates under civilian authority, Congress created and can amend the U.C.M.J. like any other federal law. The U.C.M.J. not only covers exclusive military issues such as desertion or failure to follow orders, but it also includes crimes found in civilian criminal codes such as assault, burglary, and rape. Because the President is Commander in Chief, he can unilaterally set punishment limits and make other procedural rules for military law. ${ }^{25}$ Although members of the military retain their constitutional rights, they are modified to include the government's substantial interests of raising and maintaining a military, retaining good order and discipline, and fighting and winning wars. ${ }^{26}$ The role of the commander in the

21. 2019 Def. Advisory Comm. on Investigation, Prosecution, and Def. of Sexual Assault in the ARmed Forces, Third Annual Report 1, https://dacipad.whs.mil/images/ Public/08-Reports/DACIPAD_Report_03_Final_20190326_Web.pdf [perma.cc/DH5U-DPNH].

22. Eric R. Carpenter, Evidence of the Military's Sexual Assault Blind Spot, 4 VA. J. CRIM. L. 144, 159 (2016).

23. 2019 Dep't of Def., Sexual Assault Accountability and Investigation Task FORCE, supra note 21, at 5. SAAITF also recommends making sexual harassment a standalone $\mathrm{UCMJ}$ violation.

24. Criminal Law Department The Judge Advocate General's Legal Center and School U.S. Army, Criminal Law Deskbook Practicing Military Justice 1-2 (2018), https://www.loc.gov/rr/frd/Military_Law/pdf/Crim-Law-Deskbook_July-2018.pdf [perma.cc/YQP5-CFLT].

25. Id.

26. Parker v. Levy, 417 U.S. 733,744 (1974). 

THE UNITED STATES MILITARY

military justice system presents the starkest contrasts to the civilian system. ${ }^{27}$ The term commander does not refer to any specific rank but is "a commissioned officer who, by virtue of that officer's grade and assignment, exercises primary command authority over a military organization or prescribed territorial area."${ }^{28}$

When there is an allegation or report of a possible violation, a commander can (1) take no action, (2) initiate administrative action, such as in an in-person reprimand or even involuntary separation from the military, (3) impose nonjudicial punishment, commonly known as an article 15 which can result in loss of rank, pay, or additional training or duty, or (4) refer charges for military courtmartial. ${ }^{29}$ Offenses punished by administrative actions and non-judicial punishments are not considered convictions and are used to deal with lesser or military-specific offenses. ${ }^{30}$ There are three types of courts-martial with procedural protections and severity of punishment increasing at each level. ${ }^{31} \mathrm{~A}$ summary court-martial may be convened by any commander who can convene a general or special court-martial or the commanding officer of a company that consists of one hundred fifty to three hundred service members. ${ }^{32}$ This court may only administer punishments of up to one month, forty-five days of hard labor, or forfeiture of no more than two-thirds of one month's pay. ${ }^{33}$ A special courtmartial may be convened by any commander who may convene a general courtmartial or the commanding officer of a brigade or regiment which consists of three to five thousand service members. ${ }^{34}$ The special court-martial may only punish service members with up to one year of confinement, hard labor for three months, or forfeiture of pay not exceeding two-thirds pay for over a year. ${ }^{35}$ Finally, a general court-martial may be convened by the President, Secretary of Defense, the Secretary concerned, or the commanding officer of a territorial department, an army group, corps, or division that consists of fifteen to forty thousand service members. ${ }^{36}$ This court may issue punishments of up to life in prison or the death penalty. ${ }^{37}$ In all cases, regardless of severity or complexity, a

27. Criminal Law Department The Judge Advocate General's Legal Center and SCHOOL U.S. ARMY, supra note 24, at 1-6; For convenience and clarity, ranks and military justice procedures will use Army specific terms.

28. U.S. Dep't of Army, Reg. 27-10, Army Command Policy qף 3-7 (2016), https://armypubs.army.mil/epubs/DR_pubs/DR_a/pdf/web/ARN18522_R27_10_admin_FINAL.pdf [perma.cc/3PT5-LEAV].

29. Criminal Law Department the Judge Advocate General's Legal Center and SCHOOL U.S. ARMY, supra note 24, at 1-6.

30. Id. 1-13.

31. 10 U.S.C.A. $\$ 816$ (West 2019).

32. 10 U.S.C.A. $\$ 820$ (West 2019).

33. $I d$.

34. 10 U.S.C.A. $\S 819$ (West 2019).

35. $I d$.

36. 10 U.S.C.A. $\S 818$ (West 2019).

37. Id. 
commander makes the final decision on whether to bring charges against the accused. ${ }^{38}$ The commander makes the initial decision whether to prosecute, and a military lawyer or judge advocate (J.A.) prosecutes. ${ }^{39}$ If a commander does not have the authority to convene a court-martial, he must refer the case to a higherranking officer with the proper convening authority. ${ }^{40}$

For the highest level of court-martial, the general court-martial, the commander must consult the staff judge advocate for advice on whether to refer charges for prosecution. ${ }^{41}$ The commander cannot refer charges for general courtmartial unless the staff J.A. advises that there is probable cause to believe that the accused committed the offense. ${ }^{42}$

\section{SEXUALLY BASED OFFENSES}

Until 2013, sexually-based offenses were handled much in the same way as any other crime. As part of the 2014 military budget, Congress passed several reforms which significantly changed how sexually-based cases are handled. ${ }^{43}$ As part of these reforms, victims are now represented by a Special Victims Counsel (S.V.C.) to protect the victim and ensure that they retain a voice in the proceedings. ${ }^{44}$ In addition, the accused can no longer rely on the "good soldier defense." Formerly, the accused's military record and character could be considered in the initial disposition of the charges and at trial. ${ }^{45}$ Also, sexual assault convictions now include a minimum sentence of separation from the military and dishonorable discharge. ${ }^{46}$

The commander's role in prosecuting sexual assaults also changed. Although there were discussions on eliminating commanders' prosecutorial discretion, commanders retained this power due to strong resistance from the Department of Defense ("DoD"). ${ }^{47}$ Commanders, however, did lose significant power because of the 2014 reforms. Formerly, the convening authority of a court-martial could overturn a jury verdict. ${ }^{48}$ This power was removed for sexual assault and other sexually-based offenses. ${ }^{49}$ Additionally, in 2013, the Secretary of Defense, by a DoD directive, required that sexual offenses may only be adjudicated by the first

38. Criminal Law Department the Judge Advocate General's Legal Center and SCHOOL U.S. ARMY, supra note 24, at 1-6.

39. Id.

40. Id.

41. 10 U.S.C.A. $\S 834$ (West 2019).

42. Id.

43. Greg Rustico, Overcoming Overcorrection: Towards Holistic Military Sexual Assault Reform, 102 VA. L. REV. 2027, 2040 (2016).

44. Id.

45. $I d$.

46. Id. at 2042-43.

47. Keehn, supra note 20, at 479.

48. Rustico, supra note 43, at 2045.

49. Id. 
O- $6^{50}$ in the accused's chain of command. ${ }^{51}$ This prevents less experienced commanders from making these decisions.

\section{A. Sexual Assault Statistics in the United States Military}

The modern era of combating sexual assault in the military began in 2004 when Secretary of Defense Donald Rumsfeld ordered a review of the Department of Defense's process for treatment of sexual assault victims. ${ }^{52}$ This order led to the creation of the Sexual Assault Prevention and Response Office ("S.A.P.R.O."). ${ }^{53}$ This body ensures that each military branch complies with DoD policy and supports and trains sexual assault and response coordinators ("S.A.R.Cs.") across the DoD. ${ }^{54}$ Before this time, there was no official compilation of military sexual assault statistics. Currently, Congress requires the Department of Defense to issue an annual report on sexual assault in the military. ${ }^{55}$ S.A.P.R.O. publishes this report and outlines efforts being taken to combat the problem. ${ }^{56}$

\section{B. Fiscal Year 2018 Survey of Workplace and Gender Relations Survey of Active Duty Members}

Sexual assault statistics for the 2018 report were compiled from a biannual survey called the Workplace and Gender Relations Survey of Active Duty Members (W.G.R.A.) conducted by the Office of People Analytics within the DoD. The W.G.R.A. surveyed 736,645 active-duty service members across the DoD and, based on an eighteen percent response rate, estimated rates of sexual assault and harassment across the military. ${ }^{57}$ The W.G.R.A.'s definition of sexual assault includes rape, sexual assault, forcible sodomy, aggravated sexual contact, abusive sexual contact, and attempts to commit these offenses as defined by the U.C.M.J. ${ }^{58}$ Sexual harassment was defined using the sexual harassment policy of the DoD. ${ }^{59}$

50. See Appendix B.

51. Criminal Law Department the Judge Advocate General's Legal Center and SCHOOL U.S. ARMY, supra note 24, at 1-6.

52. Mission \& History, U.S. Dep't of Def. Sexual Assault Prevention \& Response, https://www.sapr.mil/mission-history (last visited Feb. 28, 2021).

53. Id.

54. $I d$.

55. 2018 U.S. DeP't of Def. Rep. on SeXual Assault in the Military, supra note 13; See Appendix C.

56. 2018 U.S. Dep't of Def. ReP. On SeXual Assault in the Military, supra note 13, at $3-4$.

57. Office of People Analytics, supra note 16, at iv.

58. Id. at 3; 10 U.S.C.A. $\S 920$ (West, current through P.L. 116-56).

59. DoD defines sexual harassment as

A form of sex discrimination that involves unwelcome sexual advances, requests for 


\begin{tabular}{|l|l|l|}
\hline $\mathbf{2 0 1 8}$ W.G.R.A. Survey & Female & Male \\
\hline Sexual Assault & \multicolumn{2}{|l|}{} \\
\hline Estimated Reporting Rate & $6.2 \%(13,000)$ & $.7 \%(7,500)$ \\
\hline Sexual Harassment & $31 \%(6,353)$ & $6.3 \%(68,304)$ \\
\hline Retaliation & $24.2 \%(50,901)$ & N/A \\
\hline Active-Duty Military $^{62}$ & $21 \%{ }^{61}$ & $83.8 \%(1,084,184)$ \\
\hline
\end{tabular}

The number of women sexually assaulted increased from $4.3 \%$ in 2016 to $6.2 \%$ in $2018 .^{63}$ The estimated prevalence rate for active-duty men remained statistically unchanged during this period hovering at $0.7 \%$. ${ }^{64}$ The survey revealed that sexual assault in the military occurred most often between junior enlisted acquaintances who are peers or near peers in rank. ${ }^{65}$ According to the survey, there were roughly 20,500 sexual assault victims in 2018 but only onethird, or 6,353 , chose to report. ${ }^{66}$ This is a substantial increase in reporting compared to the nearly 1 in 14 who chose to report in $2006 .{ }^{67}$ Sexual harassment in the military also increased from 2016 by $2.8 \%$ for women and $.6 \%$ for men. ${ }^{68}$

\section{Disposition of Cases 2018}

Of 6,353 reported cases in 2018, 4,002 cases were resolved by the time the W.G.R.A. was completed in 2019, and 1,110 of these cases were outside of the

sexual favors, and other verbal or physical conduct of a sexual nature when:

- Submission to such conduct is made either explicitly or implicitly a term or condition of a person's job, pay, or career, or

- Submission to or rejection of such conduct by a person is used as a basis for career or employment decisions affecting that person, or

- Such conduct has the purpose or effect of unreasonably interfering with an individual's work performance or creates an intimidating, hostile, or offensive working environment.

Office of People Analytics, supra note 16, at 4-5.

60. 2018 U.S. Dep't of Def. Rep. on Sexual Assault in the Military, supra note 13, at 3.

61. Id. at 20; Although only twenty-one percent met the legal requirement for retaliation, sixty-seven percent reported some form of retaliation related to their report.

62. 2017 Dep't of Def., Demographics Profile of the Military Community 18, https://download.militaryonesource.mil/12038/MOS/Reports/2017-demographics-report.pdf [perma.cc/J5K2-K53M].

63. 2018 U.S. Dep't of Def. Rep. on SeXual Assault in the Military, supra note 13, at 3.

64. Id.

65. Id. at 4 .

66. Id. at 5 .

67. Id. at 9 .

68. Office of People AnAlytics, supra note 16, at ix. 
DoD's legal authority. ${ }^{69}$ Meaning that the perpetrator was either a non-service member or another entity had jurisdiction over the offense.

\begin{tabular}{|l|l|l|}
\hline Case Disposition Category $^{70}$ & Count of Case Dispositions & Share of Cases \\
\hline $\begin{array}{l}\text { Sexual Assault Investigation } \\
\text { That Can Be Considered for } \\
\text { Possible Action by DoD } \\
\text { Commanders }\end{array}$ & 2,854 & \\
\hline $\begin{array}{l}\text { Evidence Supported } \\
\text { Commander Action }\end{array}$ & 1,845 & $65 \%$ \\
\hline $\begin{array}{l}\text { Court-Martial Charge } \\
\text { Preferred }\end{array}$ & 668 & $55 \%$ \\
\hline Nonjudicial Punishment & 267 & $22 \%$ \\
\hline Administrative Discharge & 118 & $10 \%$ \\
\hline $\begin{array}{l}\text { Other Adverse Administrative } \\
\text { Action }\end{array}$ & 158 & $34 \%$ \\
\hline $\begin{array}{l}\text { Non-sexual Assault Offense } \\
\text { Action }\end{array}$ & 634 & $3 \%$ \\
\hline Unfounded & 74 & \\
\hline
\end{tabular}

Of the 668 cases that were referred for court marital, 482 were disposed of by the release of the W.G.R.A.. Of these cases, 307 (64\%) went to trial, $90(19 \%)$ accepted discharge or resignation in lieu of court-martial, and $85(18 \%)$ charges were dismissed..$^{71}$ Of the 307 that went to trial, $203(66 \%)$ were convicted of a charge at trial, and 104 (34\%) were acquitted of all charges. ${ }^{72}$

\section{COMMANDERS' DISCRETION}

Although strides have been made in reporting, overall sexual assault and sexual harassment have increased over the past several years. In considering possible reforms to reverse this trend, the commander's role in the charging and adjudication process jumps off the page for most with a legal background. There is a strong procedural argument against the practice of commanders' discretion which enables the commander to dominate the charging decision. In the law, there is value in both substance and procedure: the result and the process for getting to the result are equally important and should both be fair. This is reflected in the constitutional protections for both substantive and procedural due process.

69. U.S. Dep’t of Def. Rep. on Sexual Assault in the Military Fiscal Year 2018 Appendix B: Statistical Data on Sexual Assault 16 (Apr. 26, 2019), https://www.sapr.mil/ sites/default/files/Appendix_B_Statistical_Data_on_Sexual_Assault.pdf [perma.cc/YT3L-3CUU].

70. Id. at 18 .

71. Id. at 24 .

72. Id. 
One element of a fair procedure is an unbiased decision-maker. ${ }^{73}$ In the current military system, no matter the commander's legal expertise, a conflict of interest remains. Unlike a civilian prosecutor who only has a duty to seek justice, ${ }^{74}$ commanders have multiple interests that often compete with justice.

Commanders have a caretakers' responsibility when it comes to servicemembers subject to their command. Commanders are responsible for the health, welfare, and morale of all of their troops. The responsibility is broad; commanders must focus on the physical, material, mental, and spiritual state of their service members, civilian employees, and their families. ${ }^{75}$

Although the military justice system does seek to promulgate justice, its ultimate purpose is to enforce good order and discipline for the purpose of creating an effective military. Put succinctly,

[I]t is the primary business of armies and navies to fight or be ready to fight wars should the occasion arise . . maintain[ing] discipline is merely incidental to an army's primary fighting function. To the extent that those responsible for performance of this primary function are diverted from it by the necessity of trying cases, the basic fighting purpose of armies is not served. ${ }^{76}$

Commanders are caught up in the conflict between ensuring the health, welfare, and individual rights of their service members and maintaining readiness and proficiency in warfighting functions. Most commanders successfully navigate this conflict and realize that service members are most effective when they know that they are safe, justice will be served, and they can simply focus on doing their jobs.

There are occasions, however, when command decisions, whether conscious or otherwise, are made to facilitate the fighting and winning of wars at the expense of all else. This creates a conflict of interest between individual rights and reaching quick and decisive military justice decisions, which allow units and commanders to focus on key warfighting functions. In fact, this was one of the contributing factors that led to multiple homicides, suicides, and sexual assaults at Fort Hood over the past several years. ${ }^{77}$ An independent report on the issue stated, "Across the installation, and especially in the Combat Brigades and their supporting elements, readiness was the primary focus of all activities, while the SHARP [Sexual Harassment/Assault Response and Prevention] Program and the

73. Henry J. Friendly, "Some Kind of Hearing”, 123 U. PA. L. Rev. 1267, 1279 (1975).

74. Model Rules of Prof'L Conduct r. 3.8 cmt.1 (Am. BAr Ass'N 2016).

75. Murphy, supra note 17 , at 136-37.

76. U.S. ex rel. Toth v. Quarles, 350 U.S. 11, 17 (1955).

77. Sarah Mervosh \& John Ismay, Army Finds 'Major Flaws' at Fort Hood; 14 Officials Disciplined, N.Y. TIMES (Dec. 8, 2020), https://www.nytimes.com/2020/12/08/us/fort-hoodofficers-fired-vanessa-guillen.html. 

THE UNITED STATES MILITARY

general well-being of Soldiers was a distant second." 78 This is an extreme example of the dangers of a conflicted decision-maker exacerbated by the Army's nearly two decades of war since the September 11 th attacks. ${ }^{79}$ Often, the negative consequences are much more subtle but can be just as damaging.

Maintaining discipline while respecting individual rights and liberties is one of the oldest conflicts within the military justice system. The U.C.M.J. itself must deal with this conflict. The stated purpose of military law is to "promote justice, to assist in maintaining good order and discipline in the armed forces, to promote efficiency and effectiveness in the military establishment, and thereby to strengthen the national security of the United States." ${ }^{.80}$ Notably absent, however, is an explicit promise to champion individual rights and liberties for each service member. Although recently there has been a marked shift towards individual liberties and justice, commanders' discretion in prosecutorial situations remains. ${ }^{81}$

\section{A. Good Order and Discipline}

While critics argue that removing commanders' prosecutorial discretion is essential to creating a fair and trustworthy military justice system, the DoD and its supporters, including Senator McSally, argue that removing this power would undermine good order and discipline. ${ }^{82}$ Commanders are responsible for maintaining good order and discipline. Essential to this task is the power to decide how each case is adjudicated. ${ }^{83}$ Through this power, commanders have ultimate control over their units and can establish good order and discipline. Although often the DoD choice justification for continued reliance on commanders' discretion, the term "good order and discipline" is poorly defined. ${ }^{84}$

Besides the straightforward meaning of the words themselves, there is no established definition. ${ }^{85}$ At its core, this term refers to the environment necessary to ensure that all legal orders are followed regardless of consequence or

78. 2020 Fort Hood IndePendent Rev. Comm. ReP. 18, https://www.army.mil/e2/ downloads/rv7/forthoodreview/2020-12-03_FHIRC_report_redacted.pdf.

79. Mervosh \& Ismay, supra note 78.

80. Joint Ser. Comm. On Military Just., Manual for Courts-Martial U.S. I-1 (2019), https://jsc.defense.gov/Portals/99/Documents/2019\%20MCM\%20(Final)\%20(20190108).pdf?v er=2019-01-11-115724-610 [perma.cc/VXL9-2MPM].

81. Colonel Jeremy S. Weber, Whatever Happened to Good order and Discipline?, 66 CLEV. ST. L. REV. 123, 125 (2017).

82. Id; Tom Vanden Brook \& Deirdre Shesgreen, Senate Panel Cracks Down on Military Sex Assaults, USA TODAY (Jun. 12, 2013), https://www.usatoday.com/story/news/politics/2013/ 06/12/commanders-discretion-in-sex-assault-cases-would-be-limited/2415879/［perma.cc/RVR98N24]; 2019 DeP't of Def., SeXual Assault Account ABility and InVEStigation Task Force, supra note 21 , at 14 .

83. Brook \& Shesgreen, supra note 82.

84. Weber, supra note 81 at, 123.

85. Id. 
circumstance. The purpose of the military is to fight and win wars. As such, members of the military must be ready and willing to follow orders and perform tasks that may lead to their death or injury or the death or injury of others. Establishing a climate of good order and discipline is central to fulfilling the purpose of the military. ${ }^{86}$ In the words of George Washington, "Discipline is the soul of an army." ${ }^{87}$ The DoD argues that commanders' discretion in administering judicial and non-judicial punishment is a central component to maintaining an environment of good order and discipline ${ }^{88}$ It is likely that the term "good order and discipline" has purposely never been clearly defined in order to give commanders broad power to control and discipline their units. ${ }^{89}$ The Manual for Courts-Martial provides a somewhat circular definition.

To the prejudice of good order and discipline refers only to acts directly prejudicial to good order and discipline and not to acts which are prejudicial only in a remote or indirect sense. Almost any irregular or improper act on the part of a member of the military service could be regarded as prejudicial in some indirect or remote sense; however, this article does not include these distant effects. It is confined to cases in which the prejudice is reasonably direct and palpable. An act in violation of a local civil law or of a foreign law may be punished if it constitutes a disorder or neglect to the prejudice of good order and discipline in the armed forces. ${ }^{90}$

Because of its malleability, the term is often found on the wrong side of history to justify military opposition to desegregation, women in the military and combat roles, and inclusion of LGBT service members. ${ }^{91}$

Often, good order and discipline and readiness are served by justly punishing the wrongdoer while protecting the victim. This creates an environment where service members know that they are safe, justice will be served, and they can simply focus on doing their job. Unfortunately, due to the complexity of sexual assault, this is not understood by all commanders. The misunderstanding is evident by the twenty-one percent of sexual assault victims who reported retaliation related to their report. ${ }^{92}$ Some commanders may view allegations of sexual assault as an annoyance or distraction to their main goal of maintaining readiness in order to fight and win wars rather than a serious problem in itself. In addition, there is a strong perception that claims will result in negative career outcomes for the victim. The W.G.R.A. asked those who did not report why those

86. Id. at 173 .

87. Id. at 124.

88. 2019 Def. Advisory Comm. on Investigation, Prosecution, and Def. of Sexual ASSAUlt IN THE ARMED ForCES, supra note 21, at 6.

89. Weber, supra note 81, at 129.

90. Joint Ser. Comm. on Military Just., supra note 80, at IV-136.

91. Weber, supra note 82, at 166-68.

92. 2018 U.S. DeP'T OF Def. ReP. On SeXual Assault in the Military, supra note 13, at 9. 
chose to remain silent. Thirty-seven percent did not report because they were worried about potential negative consequences from coworkers or peers, thirtysix percent did not want to be seen as weak, thirty-four percent thought that they might get in trouble for something they had done or would get labeled a troublemaker, twenty-nine percent did not trust that the process would be fair, twenty-six percent worried about potential negative consequences from a supervisor or someone in the chain of command, and twenty-five percent thought it might hurt their performance evaluation/fitness report for their career. ${ }^{93}$

The value of taking commanders out of the decision to refer charges for court-martial is a resolution of this conflict of interest. Commanders could focus on ensuring good order and discipline, maintaining readiness, and ensuring the welfare of their troops while independent prosecutors resolve matters of criminal justice. Prosecutors are more likely to view the problem of sexual assault and harassment in its proper light and not through the lens of combat readiness.

Conversely, the military argues that commanders are an indispensable facet of the military criminal justice system and are key to eliminating sexual assault and harassment. ${ }^{94}$ They assert that sexual assault is a "commander's issue" ${ }^{95}$ and recommend enhancing the role of the commander in the military justice system. ${ }^{96}$ They claim that commanders do not hinder the military justice system and that removing them "would not improve the quality of investigations and prosecutions, or the Department's response to sexual assault."

In essence, the military has weighed the perceived benefits of good order and discipline against the risk of injustice and concluded that the benefits of retaining commanders' discretion are greater than the risk of injustice. A review of the data the military has relied on to make this decision will determine whether the military has correctly balanced these interests.

\section{B. Review of Commander Decisions}

In response to the March 2019 hearings on sexual assault in the military and at the request of Senator McSally, Acting Secretary of Defense Patrick Shanahan organized a DoD task force to review investigative and accountability processes of military sexual assault adjudication. ${ }^{98}$ The purpose of the Sexual Assault Accountability and Investigation Task Force ("SAAITF") is to develop bold recommendations for improving the military justice system. ${ }^{99}$ SAAITF is composed of high-ranking military and DoD officials, including the Judge

93. Office of People Analytics, supra note 16, at 36.

94. 2019 Def. Advisory Comm. on Investigation, Prosecution, and Def. of Sexual AsSAUlt IN THE ARMED FORCES, supra note 21, at 14.

95. Id. at 14 .

96. Id. at 13 .

97. Id. at 14 .

98. Id. at 5 .

99. Id. 
Advocate General of the Military Departments, the highest-ranking military lawyer, the director of the DoD Sexual Assault Prevention and Response Office, and the Executive Director of the DoD Office of Force Resiliency. ${ }^{100}$ The report doubles down on retaining commanders' discretion and recommends further enhancing the role of the commander in the military justice system. ${ }^{101}$

In support of continued reliance on the commander, SAAITF cites a report by the Defense Advisory Committee on Investigation, Prosecution, and Defense of Sexual Assault in the Armed Forces (DAC-IPAD) that concludes that commanders' decisions on whether to refer charges in penetrative sexual assaults were reasonable in ninety-five percent of cases reviewed.

\section{2019 Report by Defense Advisory Committee on Investigation, Prosecution, and Defense of Sexual Assault in the Armed Forces}

DAC-IPAD was formed by the Secretary of Defense as required by Congress in 2015. ${ }^{102}$ Their stated purpose is to "advise the Secretary of Defense on the investigation, prosecution, and defense of allegations of rape, forcible sodomy, sexual assault, and other sexual misconduct involving members of the Armed Forces." 103 Unlike the SAAITF, DAC-IPAD is comprised of fifteen civilians, although five of the fifteen members have military backgrounds. ${ }^{104}$ DAC-IPAD is composed of experts in the fields of forensics, evidence, military law, medicine, procedure, prosecution, and defense. ${ }^{105}$ DAC-IPAD based its recommendations on sexual assault case adjudications from 2015 to 2017 with a specific focus on the role of the commander. Their headline conclusion was that commanders acted reasonably ninety-five percent of the time when deciding whether to refer penetrative sexual cases for court-martial. ${ }^{106}$ They came to this conclusion by reviewing a random sampling of 164 cases resolved in the fiscal year 2017 out of a possible $2,055 .{ }^{107}$

The experts had access to the entirety of the unredacted case file, including statements from key witnesses, summaries of the complainant's statements, crime scene descriptions, digital forensics, and video evidence. ${ }^{108}$ The files also included disposition decisions and explanations by the commander with

100. Id. at 7 .

101. Id. at 5,14 .

102. 2019 Def. Advisory Comm. on Investigation, Prosecution, and Def. of Sexual ASSAUlt IN THE ARMED ForCES, supra note 21, at 1.

103. Id.

104. Staff, Def. Advisory Comm. on Investigation, Prosecution, and Def. of Sexual Assault IN THE ARMED ForCES, https://dacipad.whs.mil/about-us/staff [perma.cc/453F-YHF4].

105. $I d$.

106. 2019 Def. Advisory Comm. on Investigation, Prosecution, and Def. of Sexual ASSAUlt IN THE ARMED ForCES, supra note 21, at 29.

107. Id. at $18,29-30$.

108. Id. at 25-26. 

THE UNITED STATES MILITARY

occasional input from J.As. advising the commander. ${ }^{109}$ The goal of the review was not to determine whether the reviewer would have come to the same conclusion as the commander, but whether the decision was within an acceptable zone of discretion; namely, "whether the command's decision to prefer charges and initiate a criminal justice proceeding was reasonably supported by the evidence contained in the investigative file." ${ }^{\prime 10}$ Each case was independently reviewed by two members of the committee. If the initial reviewers determined that the commander acted unreasonably, a third member would review the case. ${ }^{111}$ Reviewers found ninety-five percent of commander decisions reasonable and five percent unreasonable. ${ }^{112}$

\begin{tabular}{|l|l|l|l|l|}
\hline $\begin{array}{l}\text { Charges not } \\
\text { preferred }^{113}\end{array}$ & $\begin{array}{l}\text { Unanimous } \\
\text { Reasonable }\end{array}$ & $\begin{array}{l}\text { Majority } \\
\text { reasonable }\end{array}$ & $\begin{array}{l}\text { Unanimous } \\
\text { Unreasonable }\end{array}$ & $\begin{array}{l}\text { Majority } \\
\text { Unreasonable }\end{array}$ \\
\hline 122 & $115(86 \%)$ & $10(8 \%)$ & $3(2 \%)$ & $4(3 \%)$ \\
\hline
\end{tabular}

\begin{tabular}{|l|l|l|l|l|}
\hline Charges preferred & $\begin{array}{l}\text { Unanimous } \\
\text { Reasonable }\end{array}$ & $\begin{array}{l}\text { Majority } \\
\text { reasonable }\end{array}$ & $\begin{array}{l}\text { Unanimous } \\
\text { Unreasonable }\end{array}$ & $\begin{array}{l}\text { Majority } \\
\text { Unreasonable }\end{array}$ \\
\hline 42 & $37(88 \%)$ & $3(7 \%)$ & $1(2.5 \%)$ & $1(2.5 \%)$ \\
\hline
\end{tabular}

\section{Problems with the DAC-IPAD Report}

Although the DAC-IPAD report provides helpful and needed insight into commander disposition decisions, it has several issues. The first issue is the small and limited sample size. Less than ten percent of penetrative assault cases in the studied timeframe were reviewed by the panel. Because of the serious and pervasive nature of sexual assault, non-penetrative assaults should also be used. Penetrative assaults are less common and more likely to have physical evidence making the charging decision much easier for the command authority.

Second, "acted reasonably" is not a common legal standard of review in criminal cases. The report said that reviewers determined whether the decision was within an appropriate zone of discretion based on all the evidence in the record. ${ }^{114}$ A commonly used legal standard like abuse of discretion would be more appropriate and trustworthy. This term has an independent history of usage and interpretation, unlike the standard created by DAC-IPAD. As further evidence of this issue, the report notes that commanders struggled using proper legal terminology in their final disposition reports. ${ }^{115}$ They used the terms "no

109. Id.

110. Id. at 29 .

111. Id.

112. Id. at 5 .

113. Id. at 30 .

114. Id.at 29.

115. Id. at 6 . 
probable cause," "unfounded," and "insufficient evidence" almost interchangeably. ${ }^{116}$ Individuals with prosecuting authority should know the difference between these important legal terms. They are key to making correct prosecutorial decisions. If the panel did not fully understand the final decision reached in the case, they would likely struggle to effectively review the case's final disposition.

Finally, the panel found that in five percent of cases, the commander acted unreasonably. ${ }^{117}$ If five percent of sexual assault cases were disposed of unreasonably in 2018, then over a thousand victims would be cheated of justice. ${ }^{118}$ This number would likely be lower if independent military attorneys, who understood the difference between important legal terms, were making prosecutorial decisions.

\section{E. Independent Review of Sexual Assault Cases as Compared to Other Offenses}

Although there are several issues with DAC-IPAD's report, an empirical study of non-penetrative sexual assaults suggests that commanders treat sexual assaults the same as or more seriously than simple assaults. ${ }^{119}$ Eric Carpenter, former chair of the criminal law department at the Army's law school, studied case outcomes for non-penetrative sexual assaults from 2008 to 2011 and compared them to outcomes in non-sex-based cases. ${ }^{120}$ His findings indicated that commanders treat sexual assaults the same or more seriously than simple assaults. ${ }^{121}$ They refer sexual assault charges for prosecution at the same or slightly higher rate than simple assaults. ${ }^{122}$

\section{REVIEW OF UNITED KINGDOM MILITARY AND SEXUAL ASSAULT}

Statistics and self-reporting surveys are useful but are limited in an area of study traditionally plagued by chronic underreporting. A review of a near-peer ally military that has stripped commanders of prosecutorial discretion would provide insight into whether this reform will lead to positive change. In 2006, the United Kingdom took commanders' prosecutorial powers and gave them to an independent charging authority. ${ }^{123}$ The Armed Forces Act of 2006 established an

116. Id. at $43-44$

117. Id. at 30 .

118. Calculated by taking five percent of approximately 20,500 victims in 2018 .

119. Eric R. Carpenter, An Empirical Look at Commander Bias in Sexual Assault Cases, 22 BERKELEY J. CRIM. L. 101, 104 (2017).

120. Id.; Eric R. Carpenter Biography, FLA. INT'L UNIV. https://law.fiu.edu/directory/eric-rcarpenter/ [https://perma.cc/54L9-DUYQ].

121. Carpenter, supra note 119 , at 104.

122. Id.

123. Report of the Joint Service Subcommittee Prosecutorial Authority Study 31 (Sept. 2020), https://dacipad.whs.mil/images/Public/10-Reading_Room/00_PolicyMaterials/13_ JSC_Report_Alternative_MJSystem.pdf[https://perma.cc/Z2JN-FGSQ]. 

THE UNITED STATES MILITARY

independent prosecuting authority that is now known as the Service Prosecuting Authority ("S.P.A."). ${ }^{124}$ The S.P.A. prosecutes and makes charging decisions for offenses that would require special or general courts-martial in the U.S. military. ${ }^{125}$ Commanders retained discretion to adjudicate minor criminal offenses and military-specific crimes. Commanders only have the authority to impose up to twenty-eight days of detention, extra duty, or training. ${ }^{126}$

All offenses which violate the Sexual Offences Act of 2003, the civilian law governing sexual assaults, are treated as serious offenses and are now adjudicated outside the chain of command by the S.P.A. ${ }^{127}$ Service members whose cases are heard in a disciplinary hearing can appeal to the court-martial system. The commander plays no role in cases adjudicated by the S.P.A. Investigations are conducted by military police or an independent investigative authority, and the results are sent to the S.P.A. The S.P.A. acts as a prosecutor for these cases and determines whether charges will be brought against the offender. Although staffed by officers, the S.P.A. is an independent organization within the Ministry of Defence, the U.K. equivalent of the DoD. It exists completely outside of a military chain of command. Prosecutors refer charges for court-martial if there is a realistic prospect of conviction and if it serves the interest of the armed forces. ${ }^{128}$ In the U.K., the commander has been taken out of the charging process for mid-level and serious military and non-military offenses. Unfortunately, this reform has not had the effects its proponents hoped for.

\section{A. Current Statistics}

In 2018, the Ministry of Defence and the Equal Employment Commission of the United Kingdom conducted a survey of sexual harassment and assault in their army. The U.K.'s study relied on an anonymous survey to all Regular and Reserve Army Servicewomen and a sample of Regular and Reserve Army Servicemen totaling 22,404 participants. Based on a twenty-one percent response rate, the study extrapolated statistics for the entire army. ${ }^{129}$ Unlike the United States, the U.K. defines sexual assault under the general umbrella of sexual harassment.

Sexual harassment may be defined as unwanted conduct of a sexual nature, or other conduct based on sex affecting the dignity of women and

124. Id.

125. Id. at 31-33.

126. Id.

127. Id.

128. Clare Feikert-Ahalt, Military Justice System: Adjudication of Sexual Offenses: U.K., LiBR. OF CONG., https://www.loc.gov/law/help/militaryjustice/unitedkingdom.php, [https://perma. cc/2BZE-SRHS].

129. Hannah Markson, Sexual Harassment 2018 Report (U.K.) 2-3, https://assets. publishing.service.gov.uk/government/uploads/system/uploads/attachment_data/file/ 736177/20180821_Sexual_harassment_report_2018_OS.PDF [[https://perma.cc/3AN3-V9MX]. 
men at work, which include physical, verbal and non-verbal conduct; the conduct of superiors or colleagues is unacceptable if it is unwanted, unreasonable and offensive to the recipient; the recipient's rejection or submission to the conduct is used explicitly or implicitly as a basis for a decision affecting their job, promotion, training, salary, or any other employment decision; it creates an intimidating, hostile, or humiliating working environment for the recipient and that such conduct may be in breach of the Equal Treatment Directive. ${ }^{130}$

In 2018, the United Kingdom estimated that seven percent of female service members were touched sexually; two percent were the victims of sexual assault attempts; two percent were victims of completed sexual assault; and one percent were raped. ${ }^{131}$ In the survey, it is unclear whether the behavior was only recorded once in its worst possible category or multiple times in each category, i.e., rape is also sexual touching without consent. Interpreting the numbers conservatively where each offense is counted once in the worst category possible, seven percent of women were sexually assaulted in 2018 when applying the DoD definition of sexual assault. ${ }^{132}$ In the worst-case scenario where each offense is counted in multiple categories, thirteen percent of women were sexually assaulted using the DoD standard. ${ }^{133}$ Using the same rationale, sexual assaults among males ranged from three to six percent. ${ }^{134}$ Further, at least twenty-five percent of women and six percent of men reported incidents that would amount to sexual harassment by DoD standards. ${ }^{135}$

Despite stripping commanders of their prosecutorial discretion and having a force nearly one-tenth the size of the U.S. Army, the United Kingdom faces a sexual assault problem on a similar or possibly larger scale than the United States Army ${ }^{136}$ There are many factors that account for different levels of sexual assault and harassment, and more work is required to definitively determine the effects of removing commanders' prosecutorial discretion, but it is clearly not the panacea that critics hoped for. While reducing the role of the commander in the prosecutorial decision-making process could lead to a more transparent and procedurally sound system, changing this policy will not strike at the heart of the issue and will not unequivocally yield the results desired by policymakers.

130. Id. at 9 .

131. Id. at 23 .

132. Id. 10 U.S.C.A. $\S 920$ (West 2019).

133. $I d$.

134. Id.

135. Markson, supra note 137, at 11, 22, 28. See also U.S. DeP't of Def. ReP. ON SEXUAL Assault in the Military Fiscal Year 2018, supra note 69.

136. 2019 Ministry of Def., UK Armed Forces Q. Serv. Personnel Stats. (U.K.) 4, https://assets.publishing.service.gov.uk/government/uploads/system/uploads/attachment_data/fil e/824753/201907-_SPS.pdf, [https://perma.cc/3DE9-FGJA]; Mark Cancian, U.S. Military Forces in FY 2021: Army, CTR. STRATEGIC \& INT'L STUD. (Oct. 28, 2020), https://www.csis.org/analysis/ us-military-forces-fy-2021-army [https://perma.cc/MTM5-KPSW]. 

THE UNITED STATES MILITARY

\section{IF NOT COMMANDERS’ DisCRETION, WHAT IS THE PROBLEM?}

Empirical and data-driven evaluations of sexual assault in the military point to military culture as a likely culprit. ${ }^{137}$ After Eric Carpenter concluded that commanders did not treat non-penetrative sexual assaults differently than other crimes, he continued to investigate the problem of sexual assault in the military. Eventually, he concluded that the military had a sexual assault blind spot. ${ }^{138}$ This blind spot is an impaired cognitive reasoning process that arises from incorrect views about sexual assault, rape, and the role of women in society and the military. ${ }^{139} \mathrm{He}$ argued that those who hold traditional stereotypes regarding gender roles were more likely to hold these implicit biases. ${ }^{140}$ The military as an organization is more conservative than the general population meaning that service members are more likely to hold these gender stereotypes. ${ }^{141}$ Below is a summary of self-reported political leanings comparing military leaders with nonveterans. ${ }^{142}$

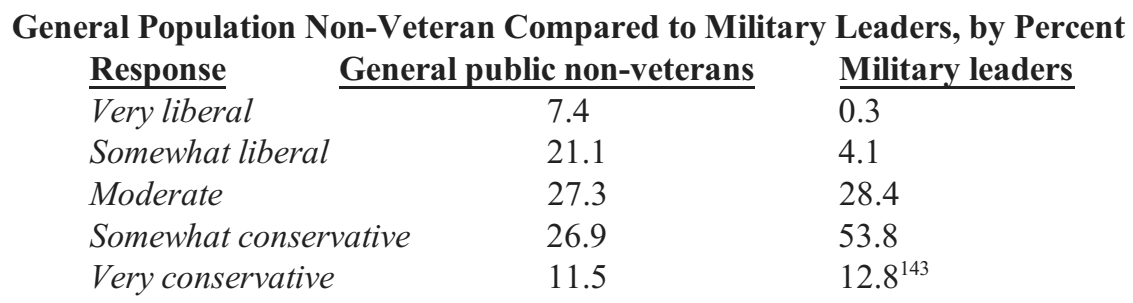

One traditional gender stereotype that Carpenter argued contributed to the military's blind spot is the belief that women should play a passive role in dating and sex, and men should be the aggressive pursuer. ${ }^{144}$ When a woman does not fit into this stereotype and is aggressive in courtship or sex, those who hold conservative gender stereotypes have trouble viewing the aggressive woman as a victim in a sexual assault scenario. They conclude that through her sexually aggressive and inappropriate behavior, she has supposedly gotten what she deserved or at least suffered the natural consequences of her behavior. Another common gender stereotype that can lead to cognitive blind spots is the belief that women should be pure, moral, and ladylike. Similarly, when women flout this

137. Carpenter, supra note 22, at 154, 160.

138. Eric R. Carpenter, The Military's Sexual Assault Blind Spot, 21 WASH. \& LeE J. Civ. RTS. \& Soc. JusT. 383 (2015).

139. Carpenter, supra note 22, at 159.

140. Id.

141. Id.

142. Carpenter, supra note 138 , at 412.

143. Id.

144. Id. at 391, 395-97. 
gender stereotype, and engage in excessive drinking, sexual behavior, or act like "one of the guys," those who hold traditional gender stereotypes struggle to view these women as victims if a sexual assault or rape scenario arises. They mistakenly believe that she has brought trouble on herself by not acting as a woman should. She has broken society's rules and has been punished accordingly. ${ }^{145}$

Although not discussed in Carpenter's work, this reasoning could also apply to the "boys will be boys" excuse often mistakenly used to excuse inappropriate behavior by men. Those who use this justification believe that a man should be sexually aggressive, dominant, and assertive and should not be punished just for acting as men "should." These beliefs are based on outdated and harmful gender stereotypes and have no place in the modern military environment.

Accounting for these traditional female stereotypes, Carpenter ran a statistical model using a dorm rape scenario and found that fifty-four percent of the general public would find the man guilty in his scenario while only forty-one percent of military decision-makers would come to the same conclusion. ${ }^{146}$ Carpenter concluded that injustice is not caused by inept or immoral commanders but harmful cognitive biases and stereotypes common in a conservative military culture.

Carpenter's research on cognitive biases, the United Kingdom's ongoing struggle with sexual assault, despite stripping commanders of prosecutorial discretion, and DAC-IPAD's findings, lead to the conclusion that policymakers should not focus on removing commanders' discretion. Instead, reforms should focus on changing the culture within the military by shifting incorrect biases and misperceptions. To achieve this objective, first, the military should continue to elevate and empower women and degender the military to combat the negative perceptions of female otherness. Second, sexual harassment should be an enumerated U.C.M.J. violation, and finally, the definition of retaliation should be broadened. Service members who sexually harass or retaliate likely hold incorrect views and attitudes about sexual assault, sexual harassment, rape, and women in the military. These violators should receive mandatory retraining that can rectify faulty biases and decision-making processes. The military cannot require offenders to change their core beliefs. However, they can send a clear message on what the standard is and set the expectation that when service members act in a military capacity, they should set aside their own beliefs and adopt the beliefs and values of the organization they serve. Correctly understanding sexual assault, sexual harassment, retaliation, and gender-neutral decision-making should be required commander competency and a standard that all service members should meet.

These reforms address and recognize the unique role the military plays in the lives of service members. "[T]he military is, by necessity, a specialized society separate from civilian society. We have also recognized that the military has, again by necessity, developed laws and traditions of its own during its long

145. Id.

146. Carpenter, supra note 22 , at 160. 

THE UNITED STATES MILITARY

history." "I47 "Indeed, unlike the civilian situation, [for Service Members], the Government is often employer, landlord, provisioner, and lawgiver rolled into one." ${ }^{\prime 148}$ Military service is not just a job but a way of life. As a result, it is often easy to forget that the military is a workplace like any other where all should be protected and respected. Codification of clear sexual harassment and retaliation standards sends a clear message and reminds service members of the true nature of their military workplace.

\section{POSSIBLE REFORMS}

\section{A. Retaliation}

One clear way to change the culture of the military and help remedy implicit bias is to implement a strict punishment for retaliation. The Manual for CourtsMartial defines retaliation as follows:

Any person subject to this chapter who, with the intent to retaliate against any person for reporting or planning to report a criminal offense, or making or planning to make a protected communication, or with the intent to discourage any person from reporting a criminal offense or making or planning to make a protected communication- (1) wrongfully takes or threatens to take an adverse personnel action against any person; or (2) wrongfully withholds or threatens to withhold a favorable personnel action with respect to any person; shall be punished as a courtmartial may direct ... An action is taken with the intent to retaliate when the personnel action taken or withheld, or threatened to be taken or withheld, is done for the purpose of reprisal, retribution, or revenge for reporting or planning to report a criminal offense or for making or planning to make a protected communication. ${ }^{149}$

Retaliation is an insidious punishment inflicted upon those with the courage to report sexual assaults. Retaliatory behavior outs those who have an incorrect understanding of the seriousness of sexual assault and harassment. Sexual assault is the problem, not its report. While there can often be a cloud of confusion or mistake surrounding sexual assault and harassment, there is no mistaking retaliation. Disregarding the military mantra of "I will never leave a fallen comrade," retaliation kicks the wounded while they are down. Its intent and message are clear: the victim, not the perpetrator, is to blame and is the cause of the problem. The message about the retaliator is also clear-they have a fundamental misunderstanding about sexual assault and harassment. They incorrectly view the reporters as the cause of the resulting damage to unit cohesion, readiness, and good order and discipline. Like anything else in the

147. Parker v. Levy, 417 U.S. 733, 743 (1974).

148. Id. at 751 .

149. JOINT SER. COMM. ON MILITARY JUST., supra note 80, at IV-133-34. 
military, retaliators have failed to meet the standard and need to be retrained at the very least. Military leadership should require mandatory training to try and rectify cognitive biases for those who retaliate against sexual assault victims and help offenders understand the true nature of the problem.

Offenders should receive retraining designed to remedy implicit bias and drive home the true nature of sexual assault and harassment. They need to understand that their behavior is a significant part of the problem. Their personnel file should permanently reflect that they have engaged in this activity. Those who offend multiple times should be subject to non-judicial punishment and possibly a U.C.M.J. 134 violation for disrupting good order and discipline.

Although sixty-four percent of sexual assault reporters experienced some type of retaliation, only twenty-one percent of sexual assault reporters met the statutory requirements for retaliation. ${ }^{150}$ This is indicative of a wider cultural problem regarding sexual assault and harassment. Only by broadening the definition of retaliation can the additional forty-three percent of retaliations be properly dealt with. Notably, the statute on retaliation is limited to official action which "affects, or has the potential to affect, that Servicemember's current position or career." 151 Acts of retaliation by peers are excluded from this definition. The definition of retaliation should be broadened to include all acts of bullying or harassment that arise from the reporting of a sexual assault or harassment regardless of whether they affect the career of the victim. Broadening the definition will help facilitate cultural change because it will trigger mandatory retraining meant to help the offender properly deal with these types of situations and alert future commanders that this service member has a problem in that area. Further, those with U.C.M.J. issues on their record are less likely to be promoted and put in positions where their problematic attitudes could harm victims.

If the retaliator is in a command position, his or her discretionary power should be removed until training is complete. If commanders are retaliating against sexual assault victims, it follows that they will not adjudicate fairly on their behalf. The issue of sexual assault is too significant, and the consequences of poor leadership are too great to allow those who have proven their ignorance or malice to retain discretionary powers. The procedural weakness inherent in granting commanders prosecutorial discretion is greatest when the commander is biased. Retaliation proves that the commander is biased and will likely abuse the significant powers given to him by the military justice system. For commanders to retain this powerful tool, they need to prove that they can be trusted and should undergo vigorous training to rectify cognitive biases.

\section{B. Sexual Harassment as a U.C.M.J. Violation}

The criminalization of sexual harassment in the U.C.M.J. is a necessary step in the fight against sexual assault because of the scope of the sexual harassment problem and its propensity to lead to sexual assault. This reform was also a

150. Office of People Analytics, supra note 16, at 38.

151. JOINT SER. COMM. ON MILITARY JUST., supra note 80, at IV-134. 

THE UNITED STATES MILITARY

recommendation of SAAITF. ${ }^{152} 24.2 \%$ of women and $6.3 \%$ of men reported an incident of sexual harassment in the fiscal year 2018. ${ }^{153}$ Women who were the victims of sexual harassment were three times more likely to experience sexual assault, and sexually harassed men were twelve times more likely to be assaulted. ${ }^{154}$ Sexual harassment was one of the strongest correlatives for a future sexual assault. ${ }^{155}$ Service members need to know that sexual harassment is not a minor or secondary issue. Sexual harassment, even in the form of jokes and offensive words, can create a dangerous sexualized environment where sexual harassment is more likely to occur. ${ }^{156}$

Critics may argue that Article 134 already exists to deal with behavior like sexual harassment. However, Article 134 has been available for the duration of the sexual assault epidemic and has not been effective in solving this problem. Article 134 is a general article that states:

Though not specifically mentioned in this chapter, all disorders and neglects to the prejudice of good order and discipline in the armed forces, all conduct of a nature to bring discredit upon the armed forces, and crimes and offenses not capital, of which persons subject to this chapter may be guilty, shall be taken cognizance of by a general, special, or summary court-martial, according to the nature and degree of the offense, and shall be punished at the discretion of that court. ${ }^{157}$

Article 134 has been used to prosecute everything from antiwar statements made during the Vietnam era to attempted suicides. ${ }^{158}$ Although it has survived constitutional vagueness challenges, it has been used less in recent years, which is evident by the reduced number of convictions based on Article 134. ${ }^{159}$ Because of the important and urgent need to combat sexual assault and harassment, the military should not rely on a vague, catchall article. Instead, Congress should draft a new statute that reflects the modern operating environment of the military and society's modern views on sexual assault and harassment. ${ }^{160}$

Another fault of Article 134 is the broad discretion given to commanders in applying this article. As previously noted, good order and discipline may be intentionally vague to give commanders discretion in dealing with disciplinary

152. 2019 Dep't of Def. Sexual Assualt Accountability and Investigation Task FORCE, supra note 21, at 5.

153. 2018 Dep't of Def. Rep. on Sexual Assualt in the Military, supra note 13, at 12.

154. Id. at 4.

155. Office of People Analytics, supra note 16, at 43.

156. Mervosh \& Ismay, supra note 77.

157. 10 U.S.C.A. $\S 934$ (West 2019).

158. Weber, supra note 81 , at $133,137-38$.

159. Id. at 152-55.

160. 2019 Dep't of Def. Sexual Assualt Accountability and Investigation Task FORCE, supra note 21, at 18. 
issues. As evidenced by the high rate of retaliation, ${ }^{161}$ some may use this discretion to not vigorously prosecute sexual harassers. Making sexual harassment its own article sends an absolute, unambiguous message about this type of behavior. ${ }^{162}$ Many senior officers have often emphasized the seriousness of stamping out sexual assault and harassment in the ranks; making sexual harassment its own article will add some bite to these promises. ${ }^{163}$ By drafting a new sexual harassment article, Congress will send a clear message to service members by defining sexual harassment and describing the exact type of behavior that is not tolerated. ${ }^{164}$

Although sexual harassment is not a crime in the United States, it is not uncommon for military members to be held to a higher standard than their civilian counterparts. Drafting a sexual harassment U.C.M.J. article will also serve to root out those who hold implicit biases against sexual assault victims. Because law and culture have a two-way relationship, changing the U.C.M.J. can also change military culture. Similar to broadening the scope of a retaliation article, criminalizing sexual assault can change cultural norms and expectations within the military, which can ultimately lead to fewer sexual assaults and greater justice for victims. Criminalizing sexual harassment gives commanders a tool to punish and identify sexual harassers as well as create a unit climate that does not tolerate sexual harassment. ${ }^{165}$

\section{Implementing Reforms of the Norwegian Military}

In addition to two specific U.C.M.J. changes, the United States should emulate the cultural reforms of the Norwegian military. Norway's military justice system has been almost completely civilianized. ${ }^{166}$ The commander can only issue administrative discipline for minor or military-specific offenses while more severe crimes are charged through the civilian criminal justice system. ${ }^{167}$

161. 2018 Dep't of Def. Rep. on SeXual Assualt in the Military, supra note 13, at 9.

162. 2019 Dep't of Def. Sexual Assualt Accountability and Investigation Task FORCE, supra note 21, at 18.

163. Michael Hill \& Lolita C. Baldor, Hagel: Cadets Must Stamp Out Sex Assault Scourge, WASH. Post (May 25, 2013), https://www.washingtonpost.com/world/national-security/hagelcadets-must-stamp-out-sex-assault-scourge/2013/05/25/a56eb43e-c563-11 e2-9fe26ee52d0eb7c1_story.html [https://perma.cc/7237-W3BA]; Wesley Morgan, Shanahan Order Clampdown on Sexual Assault, Harassment, Politico (May 2, 2019), https://www.politico. com/story/2019/05/02/shanahan-military-sexual-harassment-1297816 [https://perma.cc/2W9PMDX8]; Jeff Mason, Obama Urges U.S. Military to Stamp Out Sexual Assault, ReUTERS (May 24, 2013), https://www.reuters.com/article/us-usa-obama-naval/obama-urges-u-s-military-to-stamp-outsexual-assault-idUSBRE94N0NQ20130524 [https://perma.cc/6MUG-HS47].

164. 2019 Dep't of Def. Sexual Assualt Accountability and Investigation Task FORCE, supra note 21, at 18.

165. Id.

166. The Criminal Procedure Act 1981, c. 35 (Nor.).

167. Norway, United NATIONS (Jun. 30, 2016), https://peacekeeping.un.org/sites/default/files/ 

THE UNITED STATES MILITARY

Prosecutorial discretion is exercised by a civilian prosecutor. ${ }^{168}$ Although it is tempting to attribute Norway's strong performance to an independent charging authority, other militaries have neutral prosecutors and see similar rates of sexual assault when compared to the United States. ${ }^{169}$ Norway's approach to military gender culture, however, is truly unique and worth studying.

For decades Norway has worked to degender its military and fully integrate women into its armed forces. In 1985, they became the first North American Treaty Organization ("NATO") country to allow women to serve in combat roles. ${ }^{170}$ In 2015, they became the first NATO country and European country to make military service compulsory for both men and women. ${ }^{171}$ As part of its 2013 efforts to degenderize, Norway standardized the rules and regulations governing hairstyles for men and women. ${ }^{172}$ But perhaps the most radical step taken by Norway was its decision to desegregate barracks and allow men and women to share living quarters. ${ }^{173}$ Although initially counterintuitive, this decision was not made on a whim.

Norway's Ministry of Defense commissioned a study on combined barracks from 2011-2013. The study was completed at a Norwegian Army base and placed groups of six men and two women in a shared living space. The researchers reported a "degenderisation" effect which reduced perceived gender biases and the negative perception of the female "other" in a military environment. The women did not change to adopt the masculine culture of the male environment; instead, both genders acted differently than what was typically observed in all-

norway-fact-sheet.pdf, [https://perma.cc/PE6S-TFBC].

168. Id.; The Criminal Procedure Act 1981, supra note 166.

169. As previously noted, the U.K. uses a neutral prosecuting authority and sees similar rates of sexual assaults to the US. Canada has a system nearly identical to the UK and reported that five percent of women and one percent of men were sexually assaulted in 2016. MARKSON, supra note 135, at 14, 23; Government of Canada, The Canadian Military Justice System, (Sept. 10, 2019) https:/www.canada.ca/en/department-national-defence/corporate/reports-publications/militarylaw/judge-advocate-general-annual-report-2018-2019/chapter-two-service-tribunals-statistics.html, [perma.cc/J5G7-LPWZ].

170. Anna Mulrine, 8 Other Nations That Send Women to Combat, NAT'L GeOgRAPHIC (Jan. 25, 2013), https://www.nationalgeographic.com/news/2013/1/130125-women-combat-worldaustralia-israel-canada-norway/ [perma.cc/7CJD-LHMQ].

171. Jeff Wooten, Gender Integration into the Military: A Meta Analysis Of Norway, Canada, Israel, and the United States, UnIV. NEw ENG. 37 (Aug. 1, 2015), https://dune.une.edu/cgi/ viewcontent.cgi?article $=1033 \&$ context $=$ theses, [perma.cc/J6JF-ATHS].

172. Sarah Cummings, Military Sexual Assault: A Comparative Case Study of Sexual Assault Policies in the United States, Israel, and Norway, Bridgewater St. UnIV. 94-96 (2018), https://pdfs.semanticscholar.org/6f32/e5583e74a6c92dd180025ad11c3f2a485876.pdf [perma.cc/JN4C-N2A9].

173. Ida Irene Bergstrøm, Unisex Rooms Made Gender Insignificant in Army, Norwegian Study Finds, SCI. DAILY (Mar. 20, 2014) https://www.sciencedaily.com/releases/2014/03/ 140320111756.html [perma.cc/S82G-WDRP]. 
male or all-female barracks. The males cleaned and showered more frequently while the women engaged in less slandering and cliquish behavior. Finally, the common problem of female barracks falling outside the flow of information was also solved. The subjects reported feeling an increased level of trust in their fellow soldiers. Instead of existing as two different groups, men and women, there was only one group, the army. ${ }^{174}$ Although a small study, the initial results are promising, and more work should be done on this subject.

Finally, unlike the United Kingdom, Norway's military performs better than the United States on the issue of sexual assault and is worthy of emulation. Although there is no acceptable level of sexual assault, in a 2018 joint report prepared by Norway's Armed Forces, the Defense Research Institute and the Ministry of Defense, $1.1 \%$ of women reported that they were the victims of rape. ${ }^{175}$ By contrast, in 2018, an estimated 3.3\% of women in the United States military reported experiences consistent with rape. ${ }^{176}$

Critics might argue that one reason for Norway's success is the small size of its military. Norway only has sixteen thousand active-duty personnel across its Army, Navy, Air Force, and Special Operations. ${ }^{177}$ While the small size of the Norwegian military should be kept in mind, the dire nature of the problem in the U.S. military and Norway's substantial comparative advantage should leave policymakers open-minded. In any event, the suggested changes are not based on excluding problematic recruits or aggressive oversight, which is possible with such a small force. Cultural reforms based on the Norwegian military are designed to change military culture and are scalable to a much larger force.

For additional evidence on the dangers of female otherness in the military and the issues that can arise from a problematic culture, one only needs to review the sexual assault and harassment statistics of the United States Marine Corps. The Marine Corps is the branch of the military that has most resisted integrating women into their force and has by far the highest rates of sexual assault. ${ }^{178} 10.7 \%$ of women in the Marine Corps are estimated to have been sexually assaulted in

174. Ida Irene Bergstrom, Unisex rooms made gender insignificant in the army, KILDEN GENDER RES. (Mar. 14, 2014), http://kjonnsforskning.no/en/2015/09/unisex-rooms-made-genderinsignificant-army [perma.cc/6XCH-VUN3].

175. Christine Svendsen \& Louise Thommessen, Defense: Over 160 Say They Have Been Raped or Tried to Rape in the Past Year, Norwegian Broadcasting CoRp. (Feb. 19, 2019), https://www.nrk.no/norge/forsvaret_over-160-sier-de-har-blitt-voldtatt-eller-forsokt-voldtatt-detsiste-aret-1.14432362, [perma.cc/CW6L-E52U].

176. Office of People Analytics, supra note 16, at 29.

177. Norway, N. AtLantiC Treaty ORG., https://shape.nato.int/norway [perma.cc/7EVXLJYU].

178. Kate Germano, Separate is Not Equal in the Marine Corps, N.Y. Times (Mar. 31, 2018), https://www.nytimes.com/2018/03/31/sunday-review/marine-corps-women-segregation.html [perma.cc/S522-42UU]; 2018 DeP'T OF Def. RE. On SEXUAL Assualt IN THE Milit ARY, supra note 13, at 9; see also infra Appendix C. 

THE UNITED STATES MILITARY

2018. ${ }^{179}$ This is nearly double the Army's 2018 rate of 5.8\% ${ }^{180}$ By percentage, the Marine Corps has the lowest proportion of women of any branch, the fewest women officers of any branch, and is the only branch that still segregates men and women during initial entry training. ${ }^{181}$ By segregating women at the initial entry phase, the Marine Corps is sending a message that women are fundamentally different from men and are to be treated differently. As a result, they are perpetuating stereotypes that form the foundations for flawed cognitive processes and creating a culture of repressive female otherness. Women do not need special treatment or protection and should not be held to a different cultural standard from other service members.

The United States should follow Norway's example and continue to degender the military. These changes would be in step with current U.S. military policy. In 2015, all combat roles were opened for women, ${ }^{182}$ and by 2020, the Army will implement a new, gender-neutral physical fitness test. ${ }^{183}$ The new test will emphasize ability over age or gender. Degenderisation reforms will change the culture of the military, undo implicit and explicit biases, and remove expectational baggage from female service members. Women will no longer be viewed as outsiders in a male-dominated military environment but will be viewed as fellow service members.

\section{CONCLUSION}

The United States military is surely the greatest in the world and a flagship cultural institution for everyday Americans. As such, its members deserve to serve in an environment free from sexual assault and harassment. The purpose of this Note is to focus the public and policymakers on policies that will accomplish this goal. There are no easy answers or quick fixes for this pervasive and persistent problem. Removing commanders' prosecutorial discretion would likely result in a more procedurally sound system, but it would not address the underlying cultural problems within the military. Eliminating commanders' discretion would turn the military justice system upside down without the

179. 2018 Dep't of Def. Re. On Sexual Assualt in the Military, supra note 13, at 9.

180. Id. See also infra Appendix C.

181. Shawn Snow, Where are the Female Marines?, MARIne CORP. Times (Mar. 5, 2018), https://www.marinecorpstimes.com/news/2018/03/05/where-are-the-female-marines/ [https://perma.cc/G9RM-L2C2]; Germano, supra note 178; Demographics of the U.S. Military, COUNCIL ON FOREIGN REL. (Jul. 13, 2020) https://www.cfr.org/backgrounder/demographics-usmilitary [https://perma.cc/47VN-GJPT].

182. Jim Miklaszewski \& Halimah Abdullah, All Combat Roles Now Open to Women, Pentagon Says, NBC News (Dec. 4, 2015), https://www.nbcnews.com/news/us-news/pentagonnbc-news-all-combat-roles-now-open-women-n473581[https://perma.cc/9BMD-K3AL].

183. Thomas Brading, New Changes to ACFT Being Rolled Out to Impact all Soldiers, U.S. ARMY (Sept. 27, 2019), https://www.army.mil/article/227494/new_changes_to_acft_being_rolled_ out_to_impact_all_soldiers, [perma.cc/NJF4-W54U]. 
guarantee of true progress. A more effective policy would work to rectify cognitive blind spots which impede fair adjudication of sexual assault offenses. This can be done by implementing degenderisation policies, criminalizing sexual harassment, and broadening the definition of retaliation. 
THE UNITED STATES MILITARY

APPENDIX A

\begin{tabular}{|l|l|l|l|}
\hline \multicolumn{4}{|c|}{ Army Rank Structure } \\
\hline Officers & General of the Army & E9 & $\begin{array}{l}\text { Sergeant Major } \\
\text { of the Army }\end{array}$ \\
\hline $\begin{array}{l}\text { Reserved for } \\
\text { O10 }\end{array}$ & General & E9 & $\begin{array}{l}\text { Sergeant Major/ } \\
\text { Command } \\
\text { Sergeant Major }\end{array}$ \\
\hline O9 & Lieutenant General & E8 & Fist Sergeant \\
\hline O8 & Major General & E8 & Master Sergeant \\
\hline O7 & Brigadier General & E7 & $\begin{array}{l}\text { Sergeant First } \\
\text { Class }\end{array}$ \\
\hline O6 & Colonel & E6 & Staff Sergeant \\
\hline O5 & Lieutenant Colonel & E5 & Sergeant \\
\hline O4 & Major & E4 & Corporal \\
\hline O3 & Captain & E4 & Specialist \\
\hline O2 & First Lieutenant & E3 & $\begin{array}{l}\text { Private First } \\
\text { Class }\end{array}$ \\
\hline O1 & Second Lieutenant & E2 & $\begin{array}{l}\text { Private Second } \\
\text { Class }\end{array}$ \\
\hline & & E1 & Private \\
\hline
\end{tabular}




\section{APPENDIX B}

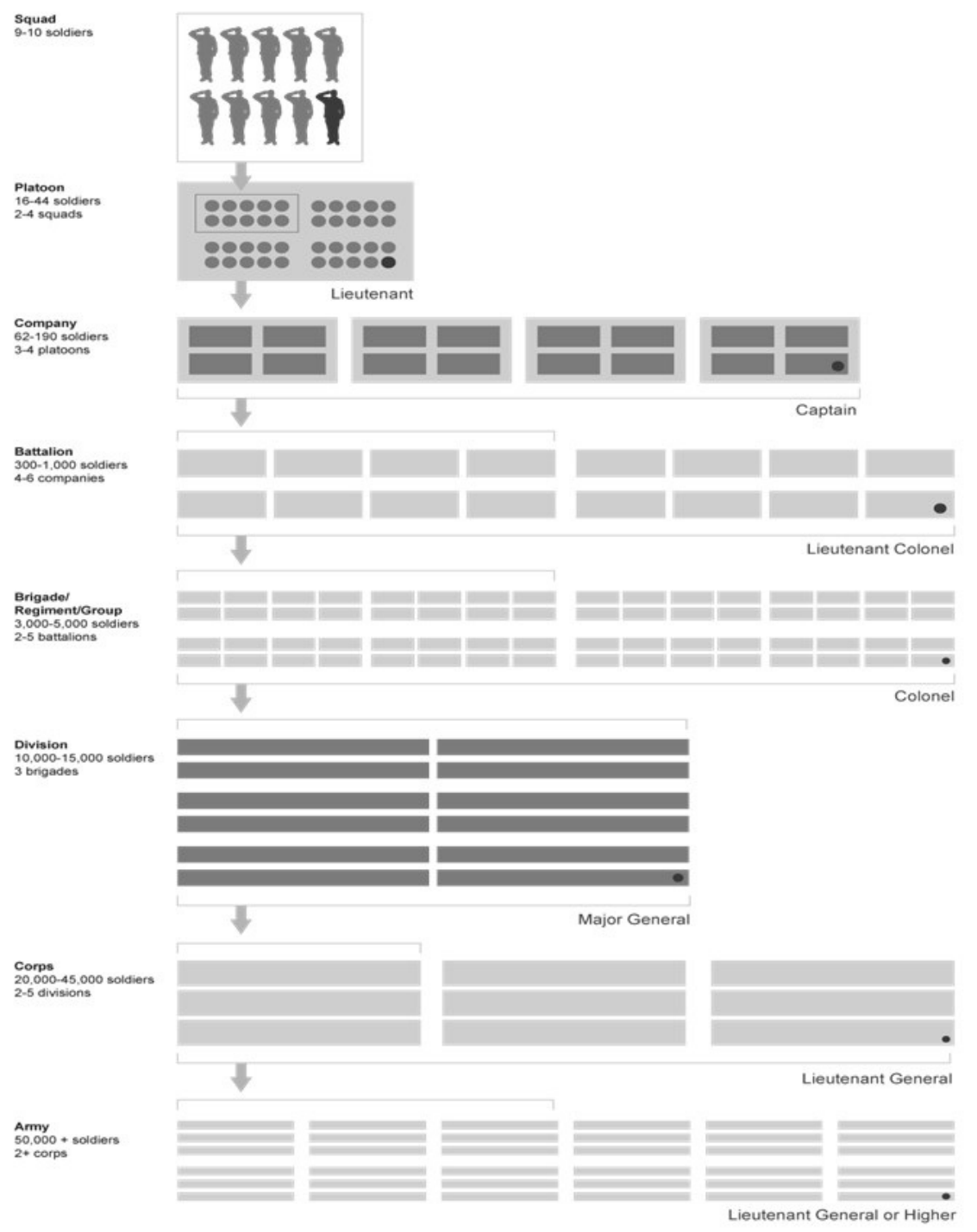




\section{APPENDIX C}

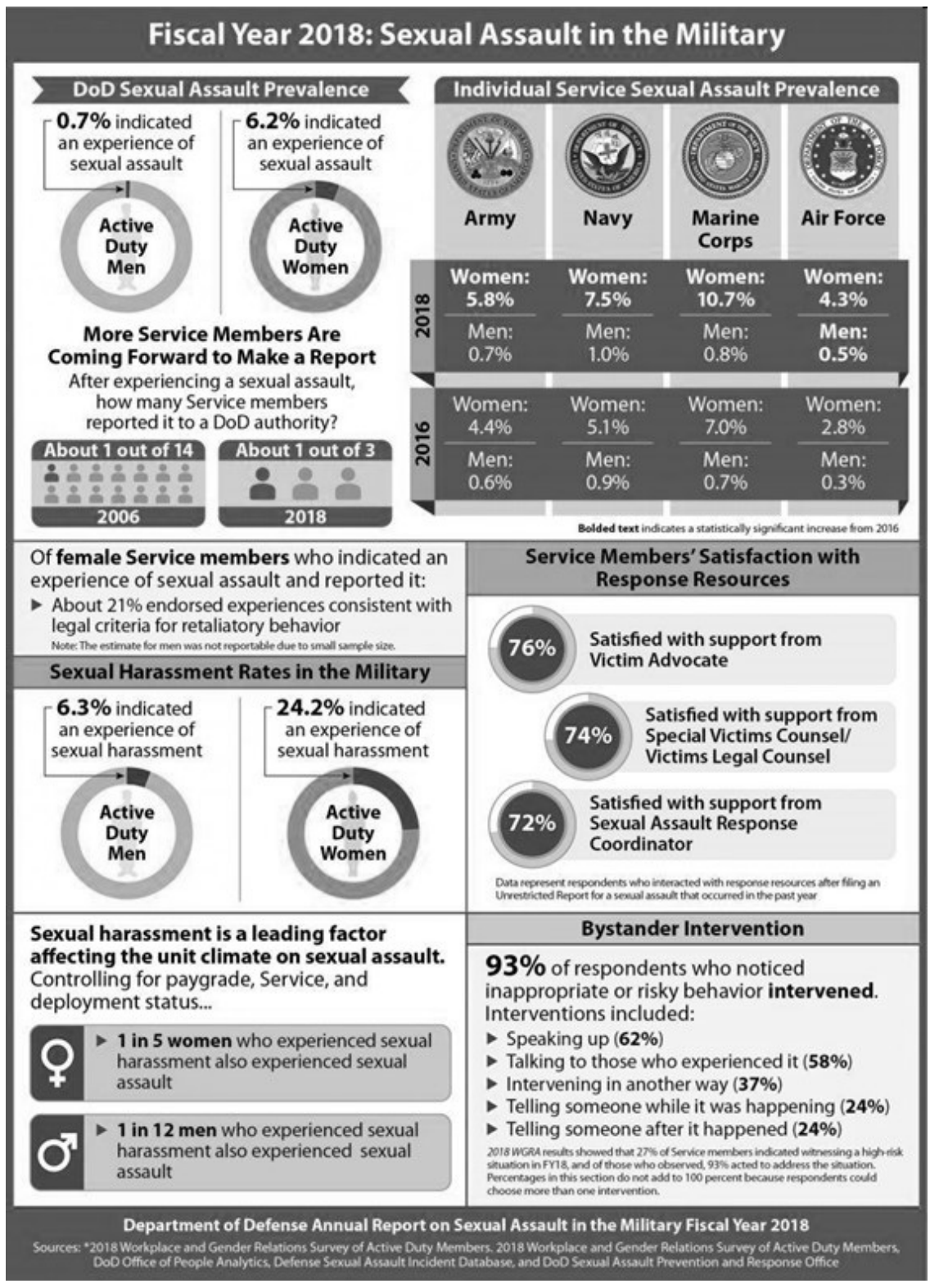

